\title{
Acute Paracetamol Poisoning
}

\author{
A. T. PROUDFOOT, ${ }^{*}$ B.sC., M.R.C.P.ED. ; N. WRIGHT, † B.SC., M.R.C.P.ED.
}

Paracetamol is generally thought to be a safe analgesic, and adverse effects following therapeutic doses have rarely been recorded. Until recently reports of acute overdosage were equally uncommon, but information regarding 15 episodes is now available (Davidson and Eastham, 1966; Thomson and Prescott, 1966; Jacobs, 1967; Pimstone and Uys, 1968; Maclean et al., 1968; Rose, 1969; Toghill, Williams, Stephens, and Carroll, 1969). The associated mortality and morbidity have been high and are not generally appreciated.

The epidemic nature of self-poisoning in Great Britain today (Central and Scottish Health Services Councils, 1968), together with the current trend to advise patients to take paracetamol rather than aspirin when a simple analgesic is required (British Medical fournal, 1967), has in our experience led to an increase in the incidence of acute paracetamol poisoning.

\section{Patients and Methods}

During the past two years 41 patients (11 males and 30 females) were admitted to the Regional Poisoning Treatment Centre at the Royal Infirmary, Edinburgh, following the ingestion of an overdose of paracetamol. Their ages ranged from 14 to 72 years. A note was made of the quantity of paracetamol said to have been ingested, other drugs or alcohol taken simultaneously or regularly within the previous six months, and a past history of liver disease. Four patients, each of whom had taken less than $7 \mathrm{~g}$. of paracetamol, were observed overnight but were not investigated. The remaining 37 had blood taken on admission for estimation of the serum bilirubin, alanine transaminase, and alkaline phosphatase. Thirty patients were under observation in hospital for a minimum of three days, liver function tests being repeated at intervals. Plasma or urine was assayed (Tompsett, 1969) for para-aminophenol. Liver function tests and electrolyte and blood glucose estimations were carried out by standard AutoAnalyzer methods.

\section{Clinical Features}

No patient gave a past history of liver disease, glandular fever, or excessive ingestion of alcohol, and only one (Case 9)

consumed alcohol with the overdose. Five patients took other drugs in addition to paracetamol at the time of the overdose (Table I) and three had been on regular drug treatment before the overdose: Case 2 with sodium amylobarbitone, ferrous sulphate, and a compound preparation containing carisoprodol, paracetamol, and caffeine; Case 7 with imipramine and dichloralphenazone; and Case 11 with phenobarbitone and penicillin.

One-third of the patients vomited within a few hours of the ingestion of the overdose. Seven others (Cases 2, 4, 6, 7, and 9-11) developed anorexia, nausea, and vomiting about 24 hours after taking the overdose, and these symptoms continued for periods of up to seven days.

Three patients (Cases 1, 2, and 5) were unconscious on arrival at hospital. In Case 5 coma was due to the barbiturate ingested with the paracetamol, and in Case 2 carisoprodol was the drug responsible.

One (Case 1) was hypoglycaemic (blood glucose $<5 \mathrm{mg} . / 100 \mathrm{ml}$.) and recovered consciousness after being given large amounts of glucose intravenously. She died of massive upper alimentary bleeding due to hypoprothrombinaemia, and was found at necropsy to have uniform necrosis of the whole liver.

Three patients (Cases 4, 5, and 9) became jaundiced. Case 5 developed acute renal failure and required haemodialysis on three occasions. She made a good recovery, and renal biopsy on the tenth day after admission showed acute tubular necrosis.

\section{Biochemical Findings}

Thirty-seven patients were investigated after paracetamol intoxication. Of 20 who showed no clinical or biochemical abnormality 14 had taken less than $15 \mathrm{~g}$. of paracetamol and six had ingested between 15 and $20 \mathrm{~g}$. Seventeen patients developed hepatocellular damage following the overdose of paracetamol. Details of these patients and the highest recorded values of serum bilirubin and alanine transaminase levels, together with the day on which peak levels occurred, are given in Table I. No abnormality of thymol turbidity was found in any patient, and only Case 1 had a raised serum alkaline phosphatase ( $30 \mathrm{~K} . A$. units $/ 100 \mathrm{ml}$.).

In addition to the profound hypoglycaemia (blood glucose $<5 \mathrm{mg}$./100 ml.) shown by Case 1 on admission to hospital three patients (Cases 2, 5, and 11) were found to have fasting blood glucose levels of 39,39 , and $36 \mathrm{mg} . / 100 \mathrm{ml}$. respectively on the third day after ingestion. Case 1 had a plasma bicarbonate of $7 \mathrm{mEq} / 1$. on admission.

Para-aminophenol metabolites were present in the blood or urine of 16 of the patients with hepatic damage but were not sought in the remaining one (Case 8 ). In some cases a second plasma level was obtained after a few hours, and these results are given in Table II.

\section{Discussion}

The cases of paracetamol poisoning reported here bring the total number recorded in the literature to 56. Analysis of these cases (Table III) clearly shows that the major complication of this type of poisoning is liver damage. The sequence of events following acute overdosage is as follows: (1) vomiting due to the irritant effect of the drug may occur within a few hours; (2) anorexia, nausea, vomiting, and epigastric pain 
Table I.-Details of 17 Patients with Liver Damage following Acute Paracetamol Poisoning

\begin{tabular}{|c|c|c|c|c|c|c|c|c|}
\hline \multirow{2}{*}{ Case No. } & \multirow{2}{*}{ Sex } & \multirow{2}{*}{ Age } & \multirow{2}{*}{$\begin{array}{l}\text { Amount of } \\
\text { Paracetamol } \\
\text { Ingested (g.) }\end{array}$} & \multirow{2}{*}{ Other Drugs Ingested } & \multicolumn{2}{|c|}{ Serum Bilirubin (mg./100 ml.) } & \multicolumn{2}{|c|}{ Serum Alanine Transaminase (units $/ \mathrm{ml}$.) } \\
\hline & & & & & Peak Level & Day & Peak Level & Day \\
\hline $\begin{array}{ll}1 \\
2\end{array}$ & $\begin{array}{l}F \\
F\end{array}$ & $\begin{array}{l}18 \\
36\end{array}$ & $\begin{array}{l}\text { Unknown } \\
\text { Unknown }\end{array}$ & $\begin{array}{l}\text { Ferrous sulphate } \\
\text { Carisoppodol. Sodium }\end{array}$ & $\begin{array}{l}4 \cdot 2 \\
1.5\end{array}$ & $\begin{array}{l}2 \\
4\end{array}$ & $\begin{array}{l}4,000 \\
>800\end{array}$ & $\begin{array}{l}2 \\
3\end{array}$ \\
\hline $\begin{aligned} 3 & . \\
4 & \cdots \\
5 & \cdots \\
6 & \cdots \\
7 & \cdots \\
8 & \cdots \\
9 & . \\
10 & \cdots \\
11 & \cdots \\
12 & \cdots \\
13 & \cdots \\
14 & \cdots \\
15 & \cdots \\
16 & \cdots \\
17 & \ldots\end{aligned}$ & $\begin{array}{l}\text { M. } \\
\text { F. } \\
\text { F. } \\
F . \\
\text { M. } \\
M . \\
M . \\
F . \\
F . \\
F . \\
F . \\
F . \\
F . \\
F . \\
F .\end{array}$ & $\begin{array}{l}19 \\
40 \\
36 \\
25 \\
72 \\
39 \\
26 \\
24 \\
25 \\
25 \\
16 \\
42 \\
31 \\
20 \\
16\end{array}$ & $\begin{array}{l}50 \\
40 \\
25 \\
25 \\
22 \cdot 5 \\
20 \\
17 \cdot 5 \\
17 \cdot 5 \\
15 \\
15 \\
13 \\
12 \\
10 \\
10 \\
6\end{array}$ & $\begin{array}{l}\text { Butobarbitone } \\
\text { Aspirin } \\
\text { Aspirin }\end{array}$ & $\begin{array}{l}0.6 \\
2.0 \\
2.5 \\
1.1 \\
1.2 \\
1.0 \\
5.3 \\
1.5 \\
1.0 \\
0.9 \\
1.6 \\
0.8 \\
0.5 \\
0.8 \\
0.4\end{array}$ & $\begin{array}{l}- \\
1 \\
2 \\
4 \\
3 \\
2 \\
2 \\
3 \\
2 \\
3 \\
2 \\
- \\
- \\
- \\
-\end{array}$ & $\begin{array}{r}87 \\
2,200 \\
>1,500 \\
>800 \\
>1,000 \\
1,520 \\
>1,900 \\
800 \\
1,000 \\
60 \\
>800 \\
82 \\
480 \\
62 \\
46\end{array}$ & $\begin{array}{l}4 \\
4 \\
2 \\
3 \\
3 \\
2 \\
4 \\
3 \\
2 \\
3 \\
2 \\
3 \\
3 \\
4 \\
1\end{array}$ \\
\hline
\end{tabular}

may be delayed for 24 hours and are probably then due to hepatic damage; (3) maximum liver damage, as assessed by alanine transaminase levels, occurs between two and four days from ingestion; in general, the degree of liver damage is greater the larger the overdose (Table I)-it is therefore a toxic effect and not a hypersensitivity phenomenon; (4) jaundice may appear after two to six days; (5) death may occur at any time from two to seven days after ingestion; the mortality is high (14\%) in the collected cases (Table III) and the most striking necropsy feature in all fatal cases has been acute hepatic necrosis.

The mortality in the present series, which includes cases of poisoning of varying severity, was $2.4 \%$. Though jaundice is the most obvious complication of paracetamol poisoning, hypoglycaemia and severe metabolic acidosis (Table 1) are even more important, as both are treatable. Only a high index of suspicion and a knowledge of the drugs which produce massive liver necrosis will conduce to early diagnosis and treatment. On the other hand, hyperglycaemia was reported by Thomson and Prescott (1966) and by Toghill et al. (1969).

The aetiology of metabolic acidosis in paracetamol poisoning is not clear, but renal failure does not seem to be the cause. Case 5 survived renal failure resulting from acute tubular necrosis complicating paracetamol poisoning. Similar renal damage has been found only in fatal cases (Davidson and Eastham, 1966; Maclean et al., 1968; Rose, 1969; Toghill et al., 1969), only one of which (Toghill et al., 1969) had required treatment for renal failure.

Table II.-Serial Plasma Para-aminophenol Levels following Acute Paracetamol Poisoning

\begin{tabular}{|c|c|c|c|c|}
\hline \multirow{2}{*}{ Case } & & \multicolumn{2}{|c|}{ Plasma Para-aminophenol (mg./100 ml.) } & \multirow{2}{*}{$\begin{array}{l}\text { Time Interval } \\
\text { (hours) }\end{array}$} \\
\hline & & First Level & Second Level & \\
\hline $\begin{array}{ll}\mathbf{A} & \cdots \\
\mathbf{B} & \cdots \\
\mathbf{C} & \cdots \\
\text { D } & \cdots \\
\text { E } & \cdots \\
\text { F } & \cdots \\
\text { G } & \cdots\end{array}$ & $\begin{array}{l}\because \\
\because \\
\because \\
\because \\
\therefore\end{array}$ & $\begin{array}{l}15 \\
23 \\
13 \\
15 \\
11 \\
11 \\
13\end{array}$ & $\begin{array}{r}6 \\
3 \\
2 \\
11 \\
12 \\
2 \\
4\end{array}$ & $\begin{array}{r}5.5 \\
15.0 \\
12.5 \\
4.0 \\
7.0 \\
13.5 \\
7.5\end{array}$ \\
\hline
\end{tabular}
TABLE III.-Complications Occurring in 56 Published Cases of Acute Para-
cetamol Poisoning

\begin{tabular}{|c|c|c|c|c|c|}
\hline Series & $\begin{array}{l}\text { No. of } \\
\text { Cases }\end{array}$ & Jaundice & $\begin{array}{c}\text { Hypo- } \\
\text { glycaemia }\end{array}$ & $\begin{array}{l}\text { Metabolic } \\
\text { Acidosis }\end{array}$ & Deaths \\
\hline Davidson and Easthan & 2 & 1 & 2 & 2 & 2 \\
\hline $\begin{array}{l}\text { Thomson and Prescott } \\
\text { (1966) } \\
\text { Jacobs (1967) } \\
\text { Pimstone and Uys }\end{array}$ & $\begin{array}{l}3 \\
1\end{array}$ & $\begin{array}{l}2 \\
1\end{array}$ & 0 & 0 & $\begin{array}{l}1 \\
0\end{array}$ \\
\hline $\begin{array}{l}\text { (1968) } \\
\text { Maclean et al. (1968) } \\
\text { Rose (1969) } \\
\text { Toghill et al. (1969)... } \\
\text { Present series }\end{array}$ & $\begin{array}{r}1 \\
5 \\
2 \\
1 \\
41\end{array}$ & $\begin{array}{l}1 \\
2 \\
2 \\
1 \\
3\end{array}$ & $\begin{array}{l}0 \\
0 \\
0 \\
4\end{array}$ & $\begin{array}{l}\frac{1}{1} \\
\frac{1}{1}\end{array}$ & $\begin{array}{l}1 \\
1 \\
1 \\
1 \\
1\end{array}$ \\
\hline Total & 56 & 13 & 6 & 5 & 8 \\
\hline
\end{tabular}

The treatment of acute paracetamol poisoning after gastric aspiration and lavage is not known. Haemodialysis was advocated by Pimstone and Uys (1968), but no measurements of its effectiveness have been made. Maclean et al. (1968) showed that peritoneal dialysis was relatively ineffective, but suggested that forced diuresis might enhance elimination of paracetamol, since $85 \%$ of the conjugated drug is excreted in the urine (Brodie and Axelrod, 1948). Rose (1969), however, suggested that forced diuresis might be particularly hazardous in this form of poisoning. The use of this technique is illogical, presumably, if forced diuresis increases elimination of only conjugated drug after it has passed through the liver cells and the damage may have been done. Higher blood levels of unconjugated paracetamol may be present in acute overdosage. Evidence on this point and on the effect of forced diuresis is lacking. Our preliminary findings (Table II) suggest that the plasma half-life of paracetamol, even in overdosage, is about four hours. In this siutation any treatment designed to enhance elimination would have to be very efficient and be put into effect soon after ingestion.

The use of antihistamines and corticosteroids in the treatment of paracetamol poisoning may have a rational basis, since these drugs have been shown in vitro to inhibit druginduced mitochondrial swelling and disruption (Judah, 1960). Their use in the cases reported by Maclean et al. (1968) was thought to have restricted hepatic damage, but those observations were uncontrolled. With the exception of one rapidly fatal case, patients in our series survived without such treatment.

We are grateful to Dr. Henry Matthew, physician in charge of the Regional Poisoning Treatment Centre, for advice, encouragement, and permission to publish details of these patients under his care; also to Dr. S. L. Tompsett, Dr. S. S. Brown, and Miss J. Cameron, of the University Department of Clinical Chemistry, who carried out the biochemical estimations.

\section{REFERENCES}

British Medical fournal, 1967, 3, 810.

Brodie, B. B., and Axelrod, J. (1948). Fournal of Pharmacology and Experimental Therapeutics, 94, 29.

Central and Scottish Health Services Councils (1968). Hospital Treatmen of Acute Poisoning. London, H.M.S.O.

Davidson, D. G. D., and Eastham, W. N. (1966). British Medical fournal, $2,497$.

Jacobs, A. (1967). Bulletin of the International Association of Forensic Toxicologists, 4 , No. 1 .

Judah, J. D. (1960). Nature, 185, 390

Maclean, D. et al. (1968). Lancet, $2,849$.

Pimstone, B. L., and Uys, C. J. (1968). South African Medical Fournal, 42, 259.

Rose, P. G. (1969). British Medical fournal, 1, 381.

Thomson, J. S., and Prescott, L. F. (1966). British Medical fournal, 2, 506

Toghill, P. J., Williams, R., Stephens, J. D., and Carroll, J. D. (1969)

Gastroenterology, 56, 773.

Tompsett, S. L. (1969). Annals of Clinical Biochemistry, 6, 81. 